\author{
Ivan GAJDOS ${ }^{1}$ \\ Emil SPIŠÁK ${ }^{2}$ \\ Ján SLOTA ${ }^{3}$ \\ Luboš KAŠČÁK ${ }^{4}$
}

\title{
INFLUENCE OF PATH GENERATION STRATEGY ON TENSILE PROPERTIES OF FDM PROTOTYPES
}

\begin{abstract}
This paper presents the results of a study evaluating the influence of path generation strategy of Fused Deposition Modeling (FDM) prototypes on mechanical properties of material. Several scientific studies were researching the problematic of path generation and internal structure of FDM prototypes. Mostly the influence on mechanical properties was observed. The presented study focuses on assessment of mechanical property of part fabricated using fused deposition modeling (FDM) technology in uniaxial tensile test. In this study standardized uniaxial tensile test (STN ISO 527-2) was used to determine tensile properties of specimens from ULTEM 9085. As the relation between mechanical property and process parameters is difficult to establish, attempt has been made to derive the empirical model between the processing parameters and mechanical properties using statistical methods. One of the parameter in path generation was the positive air-gap between fibres in internal raster. In actual practice, the parts are subjected to various types of loadings. Result show that proper model orientation when the orientation of load is known, can help to reduce the build time and material consumption.
\end{abstract}

Keywords: rapid prototyping, FDM, path generation, tensile strength

\section{Introduction}

The current market demand is for higher quality, cost reduction and greater efficiency, as well as ability to meet environmental and recycling objectives, with a consequently faster product development and reduced customer lead time. In particular, low volume products or rapidly changing high volume products require the creation of tooling for prototypes and production components, which is one of the most time consuming and costly phases. The RP process is capable

\footnotetext{
${ }^{1}$ Autor do korespondencji/corresponding author: Ivan Gajdoš, Technical University in Košice, Mäsiarska 74, 04001 Košice, Slovakia, tel.: +421 556023518, e-mail: ivan.gajdos@tuke.sk

${ }^{2}$ Emil Spišák, Technical University in Košice, Mäsiarska 74, 04001 Košice, Slovakia

3 Ján Slota, Technical University in Košice, Mäsiarska 74, 04001 Košice, Slovakia

${ }^{4}$ Luboš Kaščák, Technical University in Košice, Mäsiarska 74, 04001 Košice, Slovakia
} 
of building parts of any complicated geometry in least possible time without incurring extra cost due of absence of tooling. Another advantage of RP is to produce functional assemblies by consolidating subassemblies into single unit at the computer aided design (CAD) stage and thus to reduce part counts, handling time, and storage requirement [1]. Fused deposition modeling (FDM) is a fast growing rapid prototyping (RP) technology due to its ability to build functional parts having complex geometrical shape in reasonable time period. The quality of built parts depends on many process variables. The presented study focuses on assessment of mechanical property of tensile strength of part fabricated using fused deposition modeling (FDM) technology. As the relation between mechanical property and process parameters is difficult to establish, attempt has been made to derive the empirical model between the processing parameters and mechanical properties using statistical methods [2]. In actual practice, the parts are subjected to various types of loadings and it is necessary that the fabricated part must withhold more than one mechanical property simultaneously [3].

Ahn et al. [4] have pointed out that process parameters such as air gap and raster orientation significantly affect the tensile strength of FDM processed part as compared to other parameters like raster width, model temperature and color through experimental design and analysis. In addition, built parts exhibit anisotropic properties as far as tensile strength is concerned depending on built orientation. Khan et al. [5] have concluded that layer thickness, raster angle and air gap influence the elastic performance of the compliant FDM ABS prototype. Bahari et. al [6] determined the optimal parameter which affects the tensile strength characteristic significantly for ABS material. From the analysis, it was found that the part interior style parameter affects the tensile strength performance more greatly than others. Croccolo et al. [7] presented study of the effects generated by the Fused Deposition Modelling production parameters on the tensile strength and on the stiffness of the generated components, tackling the question from both the experimental and the numerical points of view for ABS-M30 material. Lee et al. [8] performed experiments on cylindrical parts made from three RP processes such as FDM, 3D printer and nano composite deposition (NCDS) to study the effect of build direction on the compressive strength. Experimental results show that compressive strength is $11.6 \%$ higher for axial FDM specimen as compared to transverse FDM specimen. In 3D printing, diagonal specimen possesses maximum compressive strength in comparison to axial specimen. For NCDS, axial specimen showed compressive strength $23.6 \%$ higher than that of transverse specimen. Out of three RP technologies, parts built by NCDS are severely affected by the build direction. When material is extruded from nozzle, it cools from glass transition temperature to chamber temperature causing inner stresses to be developed due to uneven deposition speed resulting in inter layer and intra layer deformation that appear in the form of cracking, delamination or even part fabrication failure. These phenomena combine to affect the part strength and size [9]. It has been observed that deformation is more in 
bottom layers than upper layers. Higher the stacking section lengths, large the deformations. If chamber temperature increases, deformation will gradually decrease and become zero when chamber temperature equals glass transition temperature of material. Therefore, it is proposed that material used for part fabrication must have lower glass transition temperature and linear shrinkage rate. Also the extruded fiber length must be small. Bellehumeur et al. [10] have experimentally demonstrated that bond quality between adjacent filaments depends on envelope temperature and variations in the convective conditions within the building part while testing flexural strength specimen. Temperature profiles reveal that temperature at bottom layers rises above the glass transition temperature and rapidly decreases in the direction of movement of extrusion head. The minimum temperature increases with the number of layers. Microphotographs indicate that diffusion phenomenon is more prominent for adjacent filaments in bottom layers as compared to upper layers. Simulation of FDM process using finite element analysis (FEA) shows that distortion of parts is mainly caused due to accumulation of residual stresses at the bottom surface of the part during fabrication [11]. The foregoing discussions reveal that FDM processed parts exhibit anisotropy of mechanical properties. Properties are sensitive to the processing parameters because parameters affect meso-structure and fibre-to-fibre bond strength. Also uneven heating and cooling cycles due to inherent nature of FDM build methodology results in stress accumulation in the built part resulting in distortion which is primarily responsible for week bonding and thus affect the strength. It is also noticed that good number of works in FDM strength modeling is devoted to study the effect of processing conditions on the part strength but no significant effort is made to develop the strength model in terms of FDM process parameters for prediction purpose. The present study uses the second order response surface model to derive the required relationship among process parameters and tensile, flexural and impact strength.

The presented study presents the influence of various path generation strategies on tensile properties of FDM prototypes made from ULTEM 9085. Path generation strategy was made with various numbers of layer contours and various air gaps between internal fibres. Internal air gap between fibres reduces the amount of used material and decreases building time.

\section{Experimental procedure}

In this study standardized uniaxial tensile test (STN ISO 527-2, speed 10 $\mathrm{mm} / \mathrm{min}$ ) was used to determine tensile properties of prepared specimens. Specimens were built on Fortus $400 \mathrm{mc}$ with slice height $0.254 \mathrm{~mm}$ and path fiber $0.508 \mathrm{~mm}$ wide. The dimensions of the test specimens were determined according to STN ISO 527 (Fig. 1) and the specimens were built in orientation as depicted in Fig. 2 with building platform parallel with XY plane in Fig. 2. Orientation of the specimens was labeled as orientation A, B and C (Fig. 2 from 
left to right). Ultem 9085 was selected as modeling material to build the samples for test. Samples were prepared with twelve different strategies of path generation. One parameter was the number of the outline contours and considering the slice dimensions in the sample with orientation A $(4 \times 10 \mathrm{~mm})$ was the number of outline contours defined as one, two and three as displayed on Fig. 3.
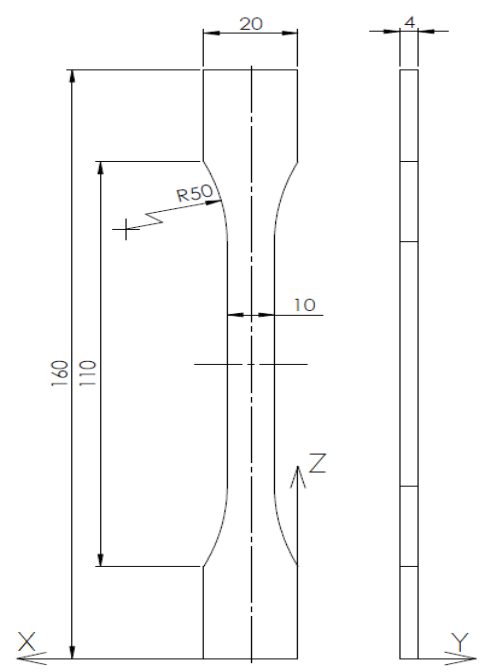

Fig. 1. Tensile test specimen dimensions

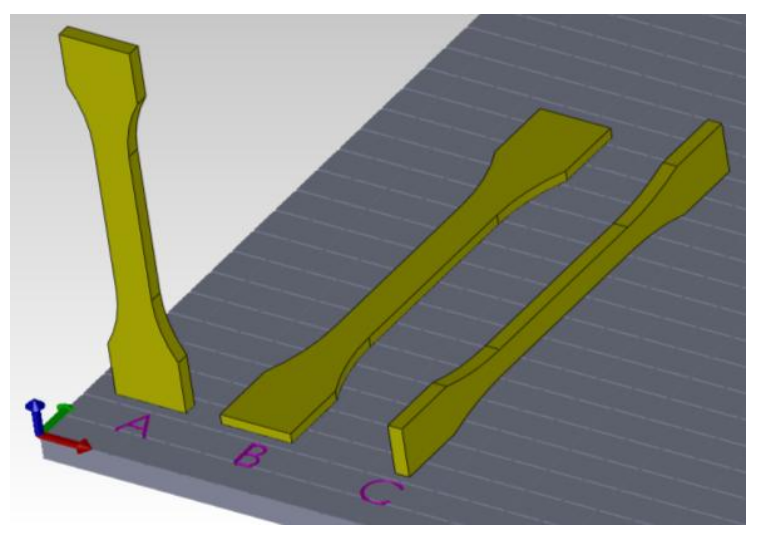

Fig. 2. Building orientation A, B and $\mathrm{C}$ (from left to right)

The second parameter in path generation was the positive air-gap between fibres in internal raster. The air gap was changed in four steps, starting at $0 \%$ of fibre width with increase to 25,50 and $75 \%$. Absolute value of air gap was 0.127 $\mathrm{mm}, 0.254 \mathrm{~mm}, 0.381 \mathrm{~mm}$. Sample of path generation with various air-gaps for slice with one outline contour is presented in Fig. 4, and generated tool path with one outline and zero air gaps in internal raster is on Fig. 3a. Combination of two a) 

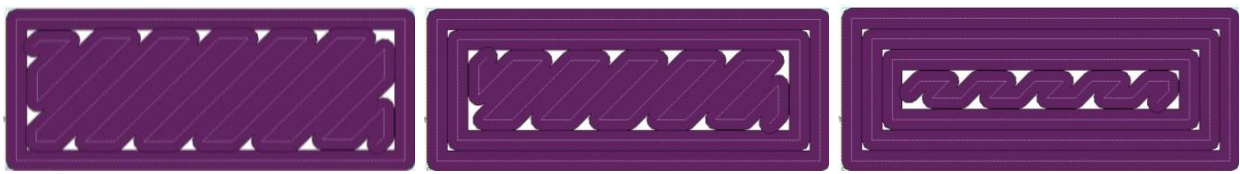

Fig. 3. Number of outline contours factor visualization for sample with orientation A with one (a), two (b) and three (c) outline contours

a)

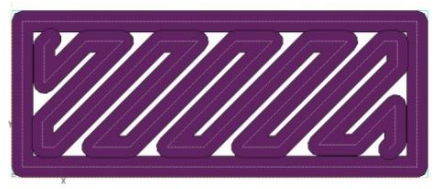

b)

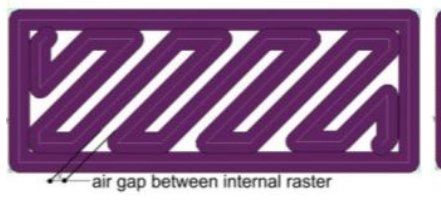

c)

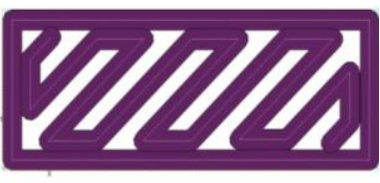

Fig. 4. Air gap in internal raster 0,127 mm (a), 0,254 mm (b) and 0,381 mm (c)

Table 1. Types of samples according to build orientation, air-gap and number of outlines

\begin{tabular}{|c|c|c|c|c|c|c|c|c|c|c|c|c|}
\hline \multirow{3}{*}{$\begin{array}{l}\text { Number } \\
\text { of outlines }\end{array}$} & \multicolumn{12}{|c|}{ Air-gap } \\
\hline & \multicolumn{3}{|c|}{$0 \mathrm{~mm}$} & \multicolumn{3}{|c|}{$0.127 \mathrm{~mm}$} & \multicolumn{3}{|c|}{$0.254 \mathrm{~mm}$} & \multicolumn{3}{|c|}{$0.381 \mathrm{~mm}$} \\
\hline & \multicolumn{3}{|c|}{ build orientation } & \multicolumn{3}{|c|}{ build orientation } & \multicolumn{3}{|c|}{ build orientation } & \multicolumn{3}{|c|}{ build orientation } \\
\hline 1 & A & $\mathrm{A}$ & A & A & $\mathrm{A}$ & A & A & A & $\mathrm{A}$ & A & A & $\mathrm{A}$ \\
\hline 2 & $\mathrm{~B}$ & $\mathrm{~B}$ & $\mathrm{~B}$ & B & $\mathrm{B}$ & $\mathrm{B}$ & B & $\mathrm{B}$ & $\mathrm{B}$ & B & $\mathrm{B}$ & $\mathrm{B}$ \\
\hline 3 & $\mathrm{C}$ & $\mathrm{C}$ & $\mathrm{C}$ & $\mathrm{C}$ & $\mathrm{C}$ & $\mathrm{C}$ & $\mathrm{C}$ & $\mathrm{C}$ & $\mathrm{C}$ & $\mathrm{C}$ & $\mathrm{C}$ & $\mathrm{C}$ \\
\hline
\end{tabular}

Fig. 5. Location of outer fiber start - end (left alignment to one line)
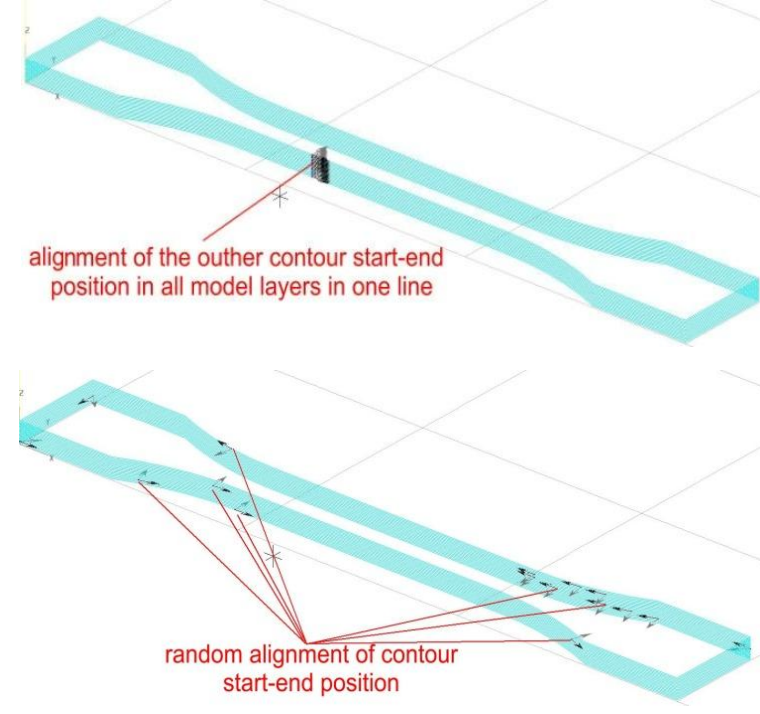
parameters and three build orientations gives 36 different types of sample internal structure (Table 1). From each type of internal structure were prepared three specimens. To minimize the influence of weak bond in point where starts and ends the path of outline fibre was the path generation parameter "seam control" set to random. Especially for the samples with orientation B and C placing the start points of the layer building in one line in $\mathrm{Z}$ direction causes weakening of the sample in this area and locates the crack always in the same area (Fig. 5).

\section{Results and discussion}

For all the proposed combinations of tool-path generation was evaluated building time of modelling material consumption obtained from software Insight 8.1 (Stratasys). Results for modelling material consumption are presented in Fig. 6 and are compared for each direction with initial tool-path generation strategy with one outline and zero air-gap. Presented results clearly show that the increasing number of the outline contours required amount of material decreases. In the case of zero air gap the difference is slightly small for each type of sample orientation. The difference is from 1.34 to $2.07 \%$. Increasing the air-gap in all types of sample orientation causes the reduction of used modelling material. Maximal reduction $29.58 \%$ of used material is observed in the sample with orientation $\mathrm{B}$, one outline and $0,381 \mathrm{~mm}$ air-gap. Maximal material consumption difference in the cases of increasing the number of outlines $19.31 \%$ can be observed in the sample with orientation A with $0.381 \mathrm{~mm}$ air-gap when changing the number of outlines from one to three.

Results for specimen building time are displayed in Fig. 7. These results show strong influence of part orientation on the building time. In the case of specimen orientation type A can be observed that with increasing of outline number the building time increases by $15.63 \%$. In the case of building specimens with orientation $\mathrm{B}$ and $\mathrm{C}$ the building time decreases. In the case of $\mathrm{C}$ orientation the building time decreases up to $6.17 \%$ and in case of B orientation decreases by $22.22 \%$. In Figure 8 are presented results for tensile strength for samples with orientation A. The results show that for samples with one and two outlines when increasing the air-gap, the tensile strength decreases. Except for the samples with $0.254 \mathrm{~mm}$ air-gap compared to $0.127 \mathrm{~mm}$ air-gap, where the tensile strength slightly increases. Samples with three outlines show interesting phenomena where with increasing the air-gap also the tensile strength increases but not like expected to decrease. That was also observed in samples with build direction $\mathrm{C}$. 


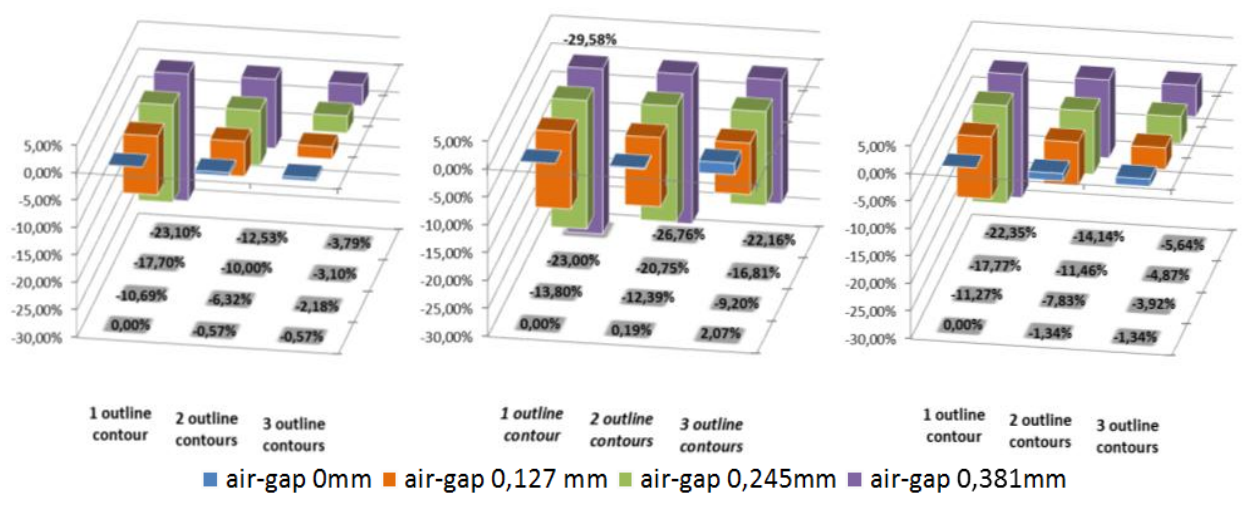

Fig. 6. Modelling material consumption compared to initial state (one outline and zero air-gap) for each samples orientation (A, B, C from left to right)

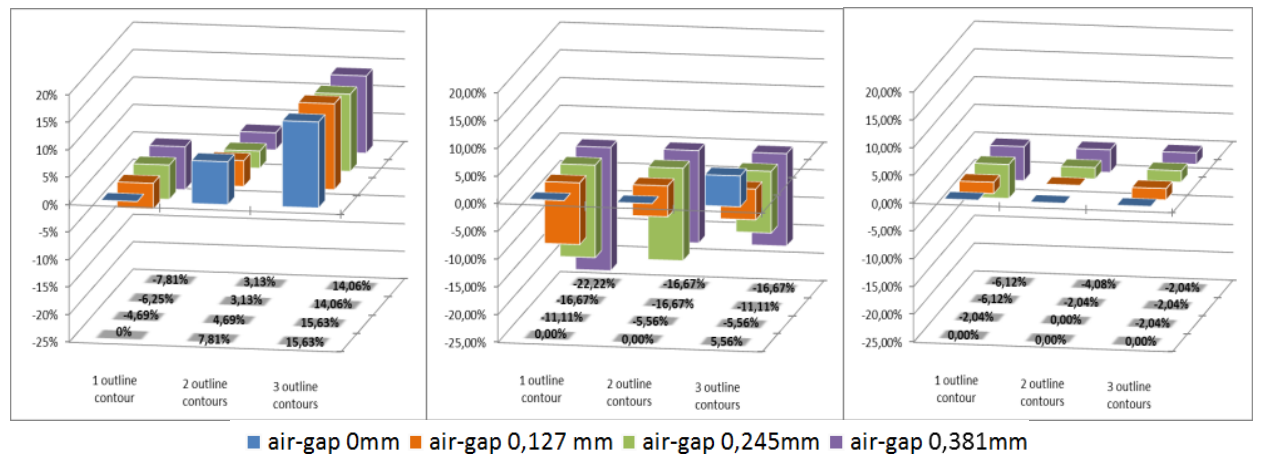

Fig. 7. Building time compared to initial state (one outline and zero air-gap) for each samples orientation (A, B, C from left to right)

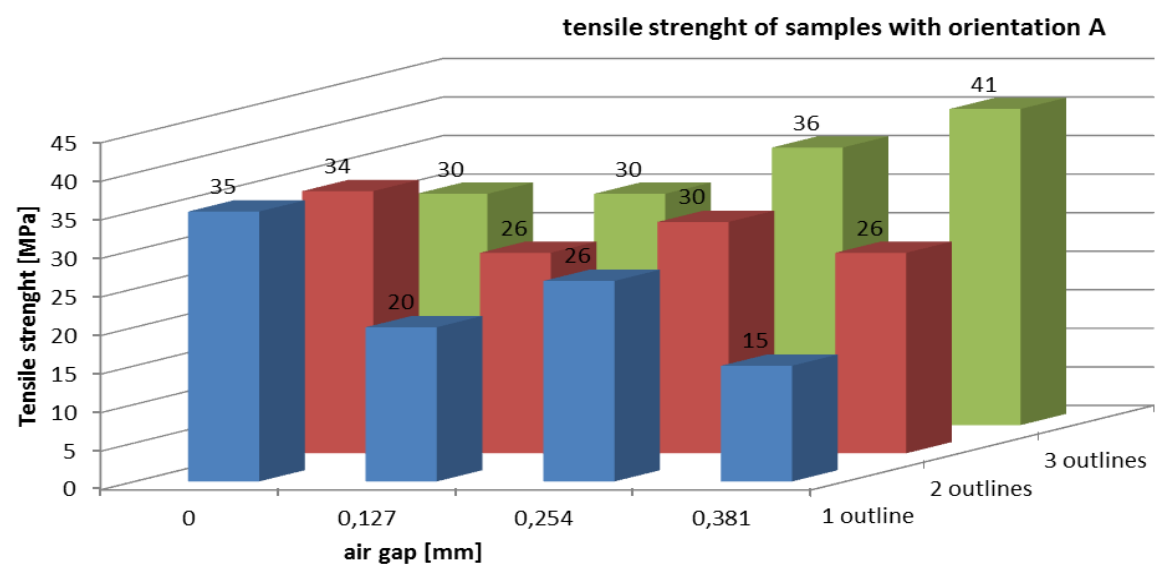

Fig. 8. Tensile strength for samples build in A orientation 
Figure 9 presents the result of tensile test for specimens with orientation B. As it was expected with increasing the air-gap the tensile strength has decreased in all variations of outlines number. Anyway the increase of the number of outlines makes the tensile strength drop less significant for the samples with three outlines compared to samples with one outline. This could be explained by the premise that larger part of the load in this orientation was carried by the internal structure. Adding an air-gap into the structure weakens the internal structure and the load must be carried by the outline fibres. Bigger number of outline fibre helps to transfer the load and prevent to drop the tensile strength so significantly compared to samples with one outline contour. Results of tensile test for samples with $\mathrm{C}$ orientation are presented in Fig. 10. As it was expected, total values of tensile strength are comparable for orientation A and B. Samples with orientation $\mathrm{C}$ have most of the outline fibres oriented in the direction of load compared to sample volume and that is why they can transfer higher load. For the samples with three outlines is observed slight increase of tensile strength with air-gap $0.127 \mathrm{~mm}$ and $0.254 \mathrm{~mm}$.

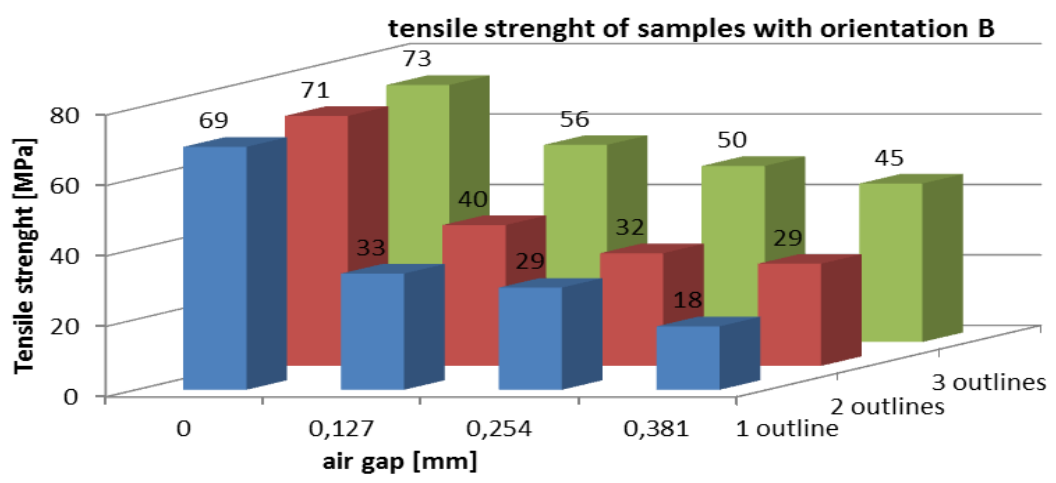

Fig. 9. Tensile strength for samples build in B orientation

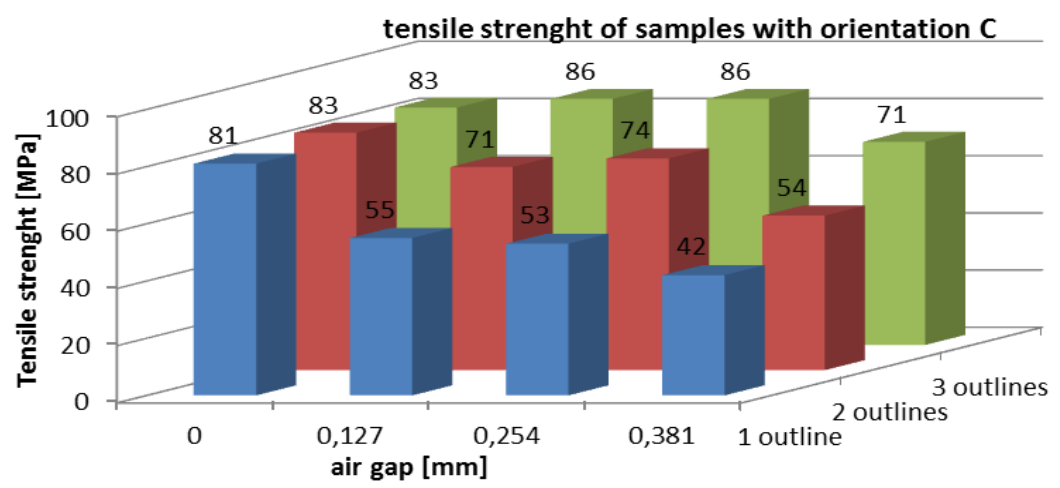

Fig. 10. Tensile strength for samples build in $\mathrm{C}$ orientation 


\section{Conclusions}

Presented paper introduced the study dealing with the influence of path generation strategy on tensile strength properties of FDM prototypes made of ULTEM 9085 material. Observed variables were the number of outline contours and air-gap in internal structure raster. The influence of selected variables on building time and modelling material consumption was observed. The tensile strength value was the highest for the samples with built orientation $\mathrm{C}$. The results from the tensile test also show, that when the operator knows the main direction of load for part built by FDM technology, he can choose the appropriate orientation and by increasing the number of outlines and adding internal air-gap. This lead to reduction of built cost, by reducing the built time and amount of used modelling material. Operator gets the part with comparable or higher mechanical properties. Anyway these phenomena of tensile strength increase require more detailed study of FDM structure and crack propagation to fully explain this mechanism.

\section{References}

[1] Budzik G.: Geometric accuracy of aircraft engine blade models constructed by means of the generative rapid prototyping methods FDM and SLA, Adv. Manuf. Sci. Technol., 34 (2010), 33-43.

[2] Gajdoš I., Slota J., Spišák E.: Non-destructive analysis of building structure in FDM prototypes, Progressive technologies and materials, 3-A Technologies, Oficyna Wydawnicza Politechniki Rzeszowskiej, Rzeszów 2009, pp. 19-27.

[3] Sood A.K., Ohdar R.K., Mahapatra S.S.: Parametric appraisal of mechanical property of fused deposition modeling processed parts, Materials Design, 31 (2010), 287-295.

[4] Ahn S.H, Montero M., Odell D., Roundy S., Wright P.K.: Anisotropic material properties of fused deposition modelling ABS, Rapid Prototyp. J., 8 (2002), 248-57.

[5] Khan Z.A., Lee B.H., Abdullah J.: Optimization of rapid prototyping parameters for production of flexible ABS object, J. Mat. Proc. Technol., 169 (2005), 54-61.

[6] Bahari M.S., Sanuddin A.B., Marlina I.K.: Investigation of optimal parameters for tensile strength property of ABS in rapid prototyping, Int. Rev. Mech. Eng., 7 (2013), 727-733.

[7] Croccolo D., De Agostinis M., Olmi G.: Experimental characterization and analytical modelling of the mechanical behaviour of fused deposition processed parts made of ABS-M30, Comput. Mat. Sci., 79 (2013), 506-518.

[8] Lee C.S., Kim S.G., Kim H.J., Ahn S.H.: Measurement of anisotropic compressive strength of rapid prototyping parts, J. Mat. Proc. Technol., 187-188 (2007), 630-637.

[9] Ming W.T., Xi J.T., Ye J.: A model research for prototype warp deformation in the FDM process, Int. J. Adv. Manuf. Technol., 33 (2007), 1087-1096. 
[10] Bellehumeur C.T., Gu P., Sun Q., Rizvi G.M.: Effect of processing conditions on the bonding quality of FDM polymer filaments, Rapid Prototyp J., 14 (2008), 72-80.

[11] Chou K., Zhang Y.: A parametric study of part distortion in fused deposition modeling using three dimensional element analysis, J. Eng. Manuf., 222 (2008), 959-67.

\title{
Ancknowledgement
}

This contribution is the result of the project implementation: International Research Staff Exchange Scheme (IRSES) FP7-PEOPLE-2010-IRSES (grant no. 269177 Co-ExIn) supported by the 7th Frame Program EU. PORSES-GA-2010-269177. Authors are grateful for the support of experimental works by project VEGA no. 1/0396/11.

\section{WPLYW STRATEGII GENEROWANIA ŚCIEŻKI PROTOTYPÓW EDM NA WŁAŚCIWOŚCI MATERIAŁU PRZY ROZCIĄGANIU}

\begin{abstract}
Streszczenie
W pracy przedstawiono wyniki badań oceniających wpływ strategii generowania ścieżki prototypów wytwarzanych metodą osadzania topionego materiału (OTM) na właściwości mechaniczne materiału. Liczne badania naukowe podejmowały problematykę generowania ścieżki oraz wewnętrznej struktury prototypów OTM. W większości przypadków zaobserwowano wpływ sposobu wytwarzania prototypów na ich właściwości mechaniczne. Prezentowane badania skupiają się na ocenie właściwości mechanicznych w teście rozciagania części wytwarzanych technologią osadzania topionego materiału. W badaniach wykorzystano znormalizowana próbę jednoosiowego rozciagania (STN ISO 527-2) do określenia właściwości przy rozciąganiu próbek z materiału Ultem 9085. Relacja pomiędzy właściwościami mechanicznymi i parametrami procesu jest trudna do ustalenia, dlatego skupiono się na określeniu modelu empirycznego pomiędzy parametrami procesu i właściwościami mechanicznymi, wykorzystując metody statystyczne. Jednym $\mathrm{z}$ parametrów generowania ścieżki była dodatnia szczelina pomiędzy włóknami wewnętrznego rastra. W praktyce części prototypowe są poddawane różnego typu obciążeniom. Wyniki badań wykazały, że poprawna orientacja części pozwala na skrócenie czasu budowy modelu oraz zmniejszenie ilości potrzebnego materiału.
\end{abstract}

Słowa kluczowe: szybkie prototypowanie, FDM, generowanie ścieżki, wytrzymałość na rozciaganie

DOI:10.7862/rm.2013.13

Otrzymano/received: 2.06 .2013

Zaakceptowano/accepted: 25.06 .2013 